\title{
Sodium Excretion during Acute Saline Loading in Dogs with Vena Caval Constriction*
}

\author{
Norman G. Levinsky † and Richard C. Lalone \\ (From the Fifth and Sixth [Boston University] Medical Services, Boston City Hospital, and \\ the Department of Medicine, Boston University School of Medicine, Boston \\ University Medical Center, Boston, Mass.)
}

The mechanisms responsible for renal sodium retention in edematous states are not completely understood. Reduced glomerular filtration and increased aldosterone secretion are often noted in subjects with edema. However, these factors, separately or in combination, do not adequately account for renal sodium retention in all clinical and experimental types of edema formation. The dog with constriction of the thoracic inferior vena cava (TVC dog) has been a useful model for the investigation of the pathophysiology of edema, especially in the studies of Davis and associates (1-7). Such dogs exhibit striking renal sodium retention and rapid collection of ascites. The increased aldosterone secretion that occurs in these dogs is not required for sodium retention, since ascites continues to form in adrenalectomized dogs maintained on a minimal amount of a mineralocorticoid hormone (2) or on a high salt intake without hormone replacement (3). The observation that sodium retention continues after transplantation of the kidney to the neck indicates that renal nerves and elevated renal venous pressure are not necessary for sodium retention (5). Although it has proven difficult to demonstrate with certainty that small decreases in glomerular filtration are not involved, suggestive data have been obtained $(1,7,8)$. Therefore, Davis and associates $(5,7)$ have concluded that factors known

* Submitted for publication July 15, 1964 ; accepted December 3, 1964.

Supported in part by U. S. Public Health Service research grants HE-06795 from the National Heart Institute and AM 05589-03 from the National Institute of Arthritis and Metabolic Diseases.

$\dagger$ Established Investigator of the American Heart Association.

Address requests for reprints to: Dr. Norman G. Levinsky, Boston University Medical Research Building, 15 Stoughton Street, Boston, Mass. 02118. to influence sodium excretion are inadequate to explain retention in TVC dogs.

In most previous work sodium retention has been studied by balance measurements of daily excretion of dietary sodium. In the present experiments, we have evaluated the response of chronic TVC dogs to saline loading and found that acute expansion of extracellular volume fails to induce natriuresis despite a large increase in glomerular filtration rate (GFR). In dogs with chronic constriction of the abdominal vena cava or with acute TVC constriction, sodium retention is less striking. The results extend previous observations and confirm prior suggestions that decreased renal hemodynamics are not required for sodium retention in TVC dogs.

\section{Methods}

We studied the response to saline loading of female mongrel dogs under light pentobarbital anesthesia. Food and water were withdrawn 18 hours before each experiment. Five $U$ of vasopressin tannate in oil and $10 \mathrm{mg}$ of desoxycorticosterone acetate (DOCA) were injected intramuscularly 18 hours and $5 \mathrm{mg}$ of DOCA $\frac{1}{2}$ hour before each study. In addition, $0.5 \mathrm{mg}$ of 2 -methyl-9 $\alpha$ fluorocortisol 1 was given intravenously at the start of each experiment. Urine was collected from an indwelling bladder catheter. An iv infusion of inulin and $p$-aminohippurate $(\mathrm{PAH})$ in water was maintained at a rate of approximately $0.5 \mathrm{ml}$ per minute throughout each experiment by a constant infusion pump. This infusion also contained 2 to $4 \mu \mathrm{g}$ per $\mathrm{ml}$ of 2 -methyl-9 $\alpha$-fluorocortisol.

When sodium excretion was stable at a rate of less than $125 \mu \mathrm{Eq}$ per minute, three to five control periods were obtained. An iv infusion of $0.82 \%$ saline was then started, and approximately $400 \mathrm{ml}$ was given initially at $30 \mathrm{ml}$ per minute. Thereafter the saline was infused at 10 to $12 \mathrm{ml}$ per minute. When $1,800 \mathrm{ml}$ had been infused, three to five additional clearance collections were made. A total volume of approximately $2,100 \mathrm{ml}$ had been

1 Donated by Dr. Harold L. Upjohn, Upjohn Co., Kalamazoo, Mich. 
TABLE I

Protocol of control and TVC studies in one dog*

\begin{tabular}{|c|c|c|c|c|c|c|c|}
\hline Time & $\mathrm{V}$ & $\mathrm{C}_{\mathrm{In}}$ & $\mathrm{C}_{\mathrm{PAH}}$ & $\begin{array}{l}\text { Plasma } \\
\text { protein }\end{array}$ & $\mathrm{P}_{\mathrm{Na}}$ & $F_{\mathrm{Na}}$ & $\mathrm{UNaV}_{\mathrm{Na}}$ \\
\hline $\min _{8 / 15 / 63}$ & \multicolumn{7}{|c|}{ Control experiment } \\
\hline $\begin{array}{r}-30 \\
0\end{array}$ & \multicolumn{7}{|c|}{$\begin{array}{l}5 \mathrm{mg} \text { DOCA intramuscularly } \\
\text { Priming dose given: } 300 \mathrm{mg} \text { inulin, } 400 \mathrm{mg} \mathrm{PAH}, 0.5 \mathrm{mg} 2 \text {-methyl-9 } \alpha \text {-fluorocortisol } \\
\text { Infusion I started: } 14 \mathrm{mg} / \mathrm{min} \text { inulin, } 5 \mathrm{mg} / \mathrm{min} \mathrm{PAH}, 1.67 \mu \mathrm{g} / \mathrm{min} 2 \text {-methyl- } 9 \alpha \text {-fluorocortisol } \\
\text { in water at } 0.55 \mathrm{ml} / \mathrm{min}\end{array}$} \\
\hline $\begin{array}{l}251-259 \\
259-267 \\
267-275\end{array}$ & $\begin{array}{l}0.44 \\
0.44 \\
0.44\end{array}$ & $\begin{array}{l}87 \\
86 \\
78\end{array}$ & $\begin{array}{l}276 \\
262 \\
326\end{array}$ & $\begin{array}{l}5.5 \\
5.5 \dagger \\
5.5\end{array}$ & $\begin{array}{l}144 \\
144 \dagger \\
143\end{array}$ & $\begin{array}{l}12.0 \\
11.8 \\
10.8\end{array}$ & $\begin{array}{l}120 \\
115 \\
123\end{array}$ \\
\hline & \multicolumn{7}{|c|}{$\begin{array}{l}\text { Infusion II started: } 0.82 \% \mathrm{NaCl} \text { at } 30 \mathrm{ml} / \mathrm{min} \\
\text { Infusion II slowed to } 12 \mathrm{ml} / \mathrm{min}\end{array}$} \\
\hline $\begin{array}{l}405-410 \\
410-415 \\
415-420 \\
420-425 \\
425-430\end{array}$ & $\begin{array}{r}9.0 \\
10.1 \\
9.0 \\
8.4 \\
8.2\end{array}$ & $\begin{array}{l}87 \\
86 \\
79 \\
80 \\
80\end{array}$ & $\begin{array}{l}304 \\
286 \\
319 \\
208 \\
233\end{array}$ & $\begin{array}{l}4.0 \\
4.0 \dagger \\
4.0 \\
4.0 \dagger \\
4.0\end{array}$ & $\begin{array}{l}142 \\
142 \dagger \\
141 \\
141 \dagger \\
140\end{array}$ & $\begin{array}{l}11.9 \\
11.7 \\
10.8 \\
10.9 \\
10.8\end{array}$ & $\begin{array}{l}1,530 \\
1,733 \\
1,467 \\
1,336 \\
1,306\end{array}$ \\
\hline $8 / 26 / 63$ & \multicolumn{7}{|c|}{ Thoracic vena cava constricted } \\
\hline $8 / 28 / 63$ & \multicolumn{7}{|c|}{ Experiment performed } \\
\hline $\begin{array}{r}-30 \\
0\end{array}$ & \multicolumn{7}{|c|}{$\begin{array}{l}5 \mathrm{mg} \text { DOCA intramuscularly } \\
\text { Priming dose given: } 300 \mathrm{mg} \text { inulin, } 400 \mathrm{mg} \mathrm{PAH}, 0.5 \mathrm{mg} 2 \text {-methyl-9 } \alpha \text {-fluorocortisol } \\
\text { Infusion I started: } 15 \mathrm{mg} / \mathrm{min} \text { inulin, } 6 \mathrm{mg} / \mathrm{min} \mathrm{PAH}, 1.67 \mu \mathrm{g} / \mathrm{min} 2 \text {-methyl- } 9 \alpha \text {-fluorocortisol } \\
\text { at } 0.53 \mathrm{ml} / \mathrm{min}\end{array}$} \\
\hline 87 & \multicolumn{7}{|c|}{ Venous pressure in abdominal vena cava $186 \mathrm{~mm}$ saline } \\
\hline $88-98$ & 0.40 & 78 & 242 & 5.4 & 142 & 10.6 & 3 \\
\hline $98-108$ & 0.35 & 81 & 240 & 5.3 & 144 & 11.2 & 5 \\
\hline $108-118$ & 0.35 & 81 & 246 & 5.4 & 143 & 11.0 & 6 \\
\hline $118-128$ & 0.35 & 87 & 257 & 5.2 & 145 & 12.0 & 5 \\
\hline $\begin{array}{l}129 \\
142\end{array}$ & \multicolumn{7}{|c|}{ Infusion II started: $0.82 \% \mathrm{NaCl}$ at $30 \mathrm{ml} / \mathrm{min}$} \\
\hline 250 & \multicolumn{7}{|c|}{$\begin{array}{l}\text { Infusion II slowed to } 12 \mathrm{ml} / \mathrm{min} \\
\text { Venous }\end{array}$} \\
\hline $250-255$ & & 91 & 263 & & 146 & 12.9 & 40 \\
\hline $255-260$ & 1.0 & 91 & 265 & $3.7 \dagger$ & $145 \dagger$ & 12.8 & 36 \\
\hline $260-265$ & 1.0 & 95 & 273 & 3.7 & 144 & 13.2 & 43 \\
\hline $265-270$ & 1.0 & 95 & 281 & $3.7 \dagger$ & $144 \dagger$ & 13.2 & 49 \\
\hline $270-275$ & 1.0 & 93 & 266 & 3.6 & 144 & 13.1 & 43 \\
\hline
\end{tabular}

* Abbreviations are as follows: TVC, constriction of the thoracic inferior vena cava; $V$, urine flow; $\mathrm{C}_{\mathrm{In}}$, inulin clearance; $\mathrm{C}_{\mathrm{PAH}}, p$-aminohippurate clearance; $\mathrm{P}_{\mathrm{Na}}$, plasma sodium; $\mathrm{F}_{\mathrm{Na}}$, filtered sodium; $\mathrm{U}_{\mathrm{Na}} \mathrm{V}$, sodium excretion; $\mathrm{DOCA}$, desoxycorticosterone acetate.

† Interpolated value.

infused by the end of the clearance periods. In some experiments, further collections were made after $2,800 \mathrm{ml}$ and again after $3,800 \mathrm{ml}$ of saline had been infused.

Dogs were studied under four conditions: control, chronic constriction of the inferior vena cava in the thorax above the entrance of the hepatic veins (TVC dogs), chronic constriction of the vena cava in the abdomen above the renal veins but below the hepatic veins (AVC dogs), and $1 \frac{1}{2}$ hours after constriction of the thoracic inferior vena cava (acute TVC dogs). The TVC and AVC dogs were studied 2 to 8 days after surgery. In most cases, a dog was studied both as a control and later as a TVC or an AVC dog. At surgery, the vena cava was constricted with a tantalum band until venous pressure below the constriction was about 18 $\mathrm{cm}$ of saline. At the time of study, caval pressure was measured with a saline-filled manometer and a catheter passed via a femoral vein approximately to the level of the renal veins. Only dogs in which venous pressure was between 18 and $40 \mathrm{~cm}$ throughout the saline-loading experiment are included in this report.

Analytical methods used in this laboratory have been listed elsewhere (9). Data in figures and tables are derived from the means of three to five consecutive clearance periods. The calculation of filtered sodium includes a correction for the Donnan factor (9). Statistical significance was determined by use of the Fisher $t$ test, applying a modification for heterogeneous variance where appropriate (10).

\section{Results}

TVC dogs. Protocols of paired experiments in one dog studied before and after TVC constriction are given in Table I. In the control experiment, sodium excretion rose from $120 \mu \mathrm{Eq}$ per minute to more than $1,300 \mu \mathrm{Eq}$ per minute after the infusion of $2 \mathrm{~L}$ of saline. GFR and 

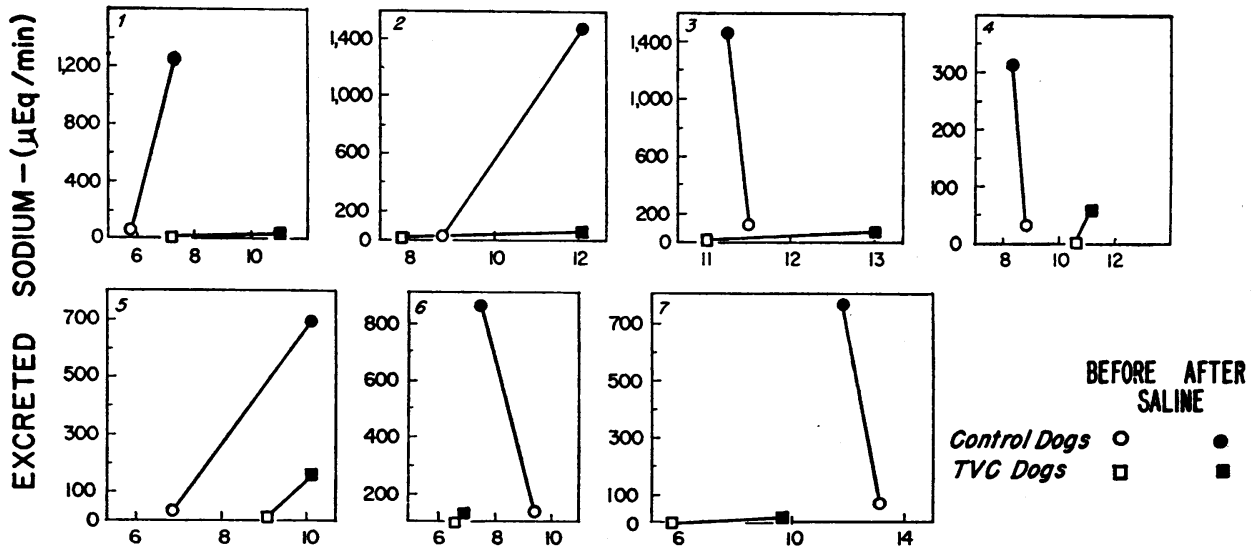

FILTERED SODIUM $-(\mathrm{mEq} / \mathrm{min})$

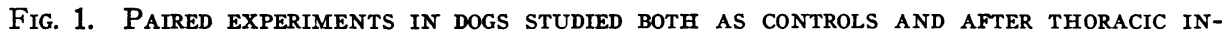
FERIOR VENA CAVAL (TVC) CONSTRICTION. The studies in a single dog are enclosed in each box. Each point is the mean of three to five clearance periods.

TABLE II

Protocol of control and $A V C$ studies in one dog*

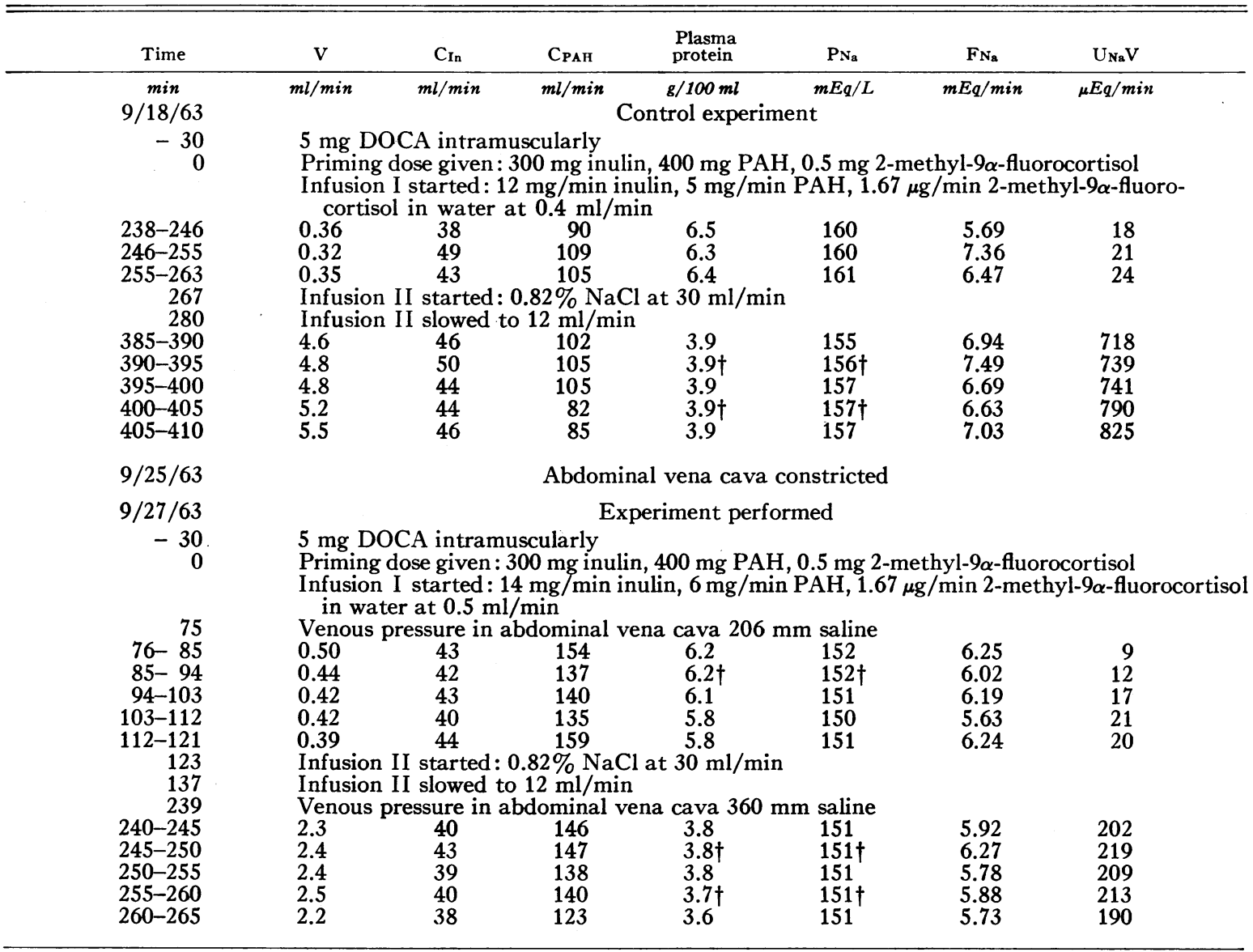

* Abbreviations as in Table $\mathrm{I}$; AVC $=$ constriction of the abdominal vena cava.

$\dagger$ Interpolated value. 
filtered sodium were unchanged. Eleven days later, the vena cava was constricted, and 2 days after surgery the saline-loading experiment was repeated. GFR and filtered sodium before the saline infusion were approximately the same as in the control experiment. After saline, GFR and filtered sodium increased about $15 \%$, to values clearly above those at any time during the control experiment. Nevertheless, there was little change in sodium excretion after saline loading during TVC constriction. Plasma protein and sodium concentrations before and after saline loading were comparable in the two experiments.

Data from paired experiments in seven dogs are illustrated in Figure 1. In each case, the increase in sodium excretion in response to saline infusion was markedly reduced after TVC constriction. In dogs 1 through 5 , the striking difference in sodium excretion between the paired experiments cannot be explained by changes in filtered sodium. In each of these experiments, filtered sodium after TVC constriction was equal to or higher than filtered sodium in the same dog studied as a control. Filtered sodium was decreased during TVC constriction in dogs 6 and 7 , and this may be partly responsible for the decreased sodium diuresis in these dogs.

The data from all ten dogs studied after TVC constriction and from 14 dogs studied in the control state are summarized in Table III. Seven dogs were tested both as controls and after TVC constriction (Figure 1); the other TVC dogs were studied only once. (The additional seven control dogs are from paired AVC studies described below.) In response to saline loading, GFR increased $16 \mathrm{ml}$ per minute in the TVC dogs, significantly more than the $5 \mathrm{ml}$ per minute rise in the controls. In spite of the greater rise in GFR and filtered sodium in the TVC dogs, sodium excretion increased only $48 \mu \mathrm{Eq}$ per minute, a trivial change in comparison to the increase of $860 \mu \mathrm{Eq}$ per minute in the control dogs. The dilution of plasma proteins after infusion of $2,100 \mathrm{ml}$ of saline was approximately the same in the two groups of dogs, suggesting that the same proportion of the saline was retained in the plasma compartment.

$A V C$ dogs. The protocols of saline-loading experiments performed before and after AVC constriction in one dog are given in Table II. In the control experiment, sodium excretion increased about $750 \mu \mathrm{Eq}$ per minute in response to the infusion of $2,100 \mathrm{ml}$ of saline. GFR increased $3 \mathrm{ml}$ per minute and filtered sodium approximately $0.5 \mathrm{mEq}$ per minute. Two days after AVC constriction, the response to saline loading was again tested. Sodium excretion increased only $200 \mu \mathrm{Eq}$ per minute after $2,100 \mathrm{ml}$ of saline. GFR before saline infusion was approximately equal to presaline GFR in the control experiment. After saline loading, GFR fell $3 \mathrm{ml}$ per minute and filtered sodium $0.15 \mathrm{mEq}$ per minute. The reduction of $550 \mu \mathrm{Eq}$ per minute in the sodium excretory response after AVC constriction may
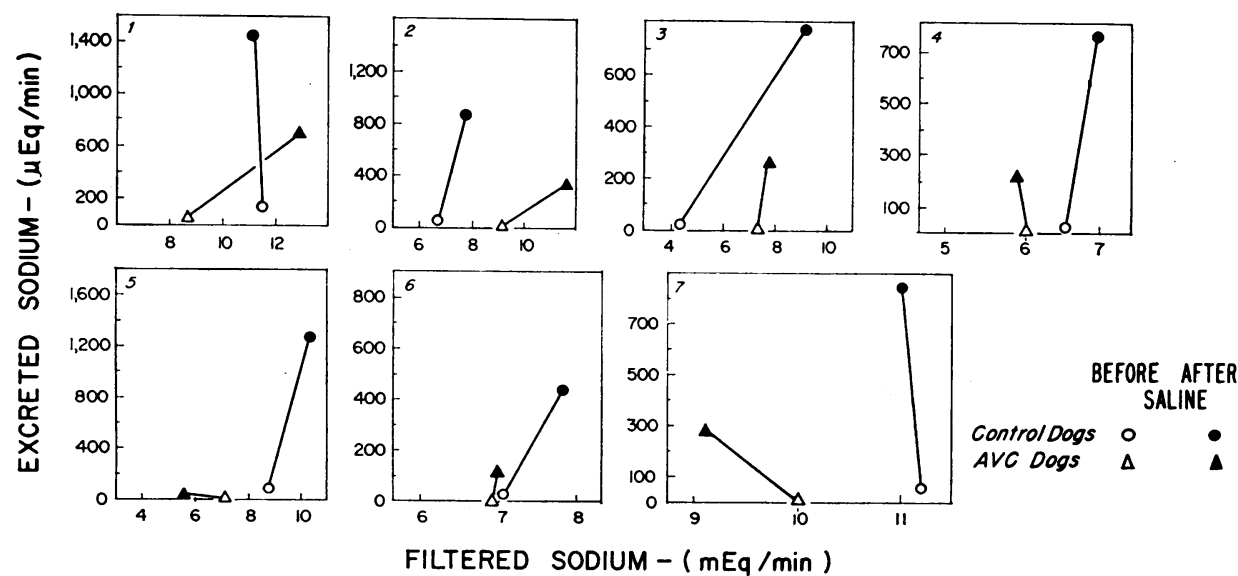

Fig. 2. PAIRED EXPERIMENTS IN DOGS STUdied Both AS CONTROLS AND AFTER ABDominal veNA CAVAL (AVC) Constriction. The studies in a single dog are enclosed in each box. Each point is the mean of three to five clearance periods. 
TABLE III

Summary of all experiments*

\begin{tabular}{|c|c|c|c|c|c|c|c|c|c|c|c|c|c|}
\hline & \multicolumn{2}{|c|}{$\mathrm{C}_{\text {In }}$} & \multicolumn{2}{|c|}{$\mathrm{C}_{\text {PAH }}$} & \multicolumn{2}{|c|}{$\mathrm{UNa}_{\mathrm{Na}}$} & \multicolumn{2}{|c|}{$\mathbf{F}_{\mathrm{Na}}$} & \multicolumn{2}{|c|}{$\begin{array}{l}\text { Plasma } \\
\text { protein }\end{array}$} & \multirow[b]{2}{*}{$\Delta \mathrm{C}_{\mathbf{I n}}$} & \multirow[b]{2}{*}{$\Delta \mathrm{U}_{\mathrm{Na}} \mathrm{V}$} & \multirow[b]{2}{*}{$\Delta \mathrm{F}_{\mathrm{Na}}$} \\
\hline & Pre & Postf & Pre & Post $f$ & Pre & Postt & Pre & Post‡ & Pre & Post & & & \\
\hline & \multicolumn{2}{|c|}{$m l / m i n$} & \multicolumn{2}{|c|}{$m l / m i n$} & \multicolumn{2}{|c|}{$\mu E q / \min$} & \multicolumn{2}{|c|}{$m E q / \min$} & \multicolumn{2}{|c|}{$\mathrm{g} / 100 \mathrm{ml}$} & $m l / \min$ & $\mu E q / \min$ & $m E q / \min$ \\
\hline $\begin{array}{l}\text { Control dogs } \\
(n=14)\end{array}$ & $\begin{array}{r}58 \\
\pm 17\end{array}$ & $\begin{array}{r}63 \\
\pm 14\end{array}$ & $\begin{array}{r}145 \\
\pm 62\end{array}$ & $\begin{array}{r}142 \\
\pm 57\end{array}$ & $\begin{array}{r}48 \\
\pm 12\end{array}$ & $\begin{array}{r}908 \\
\pm 350\end{array}$ & $\begin{array}{r}8.63 \\
\pm 2.49\end{array}$ & $\begin{array}{r}9.57 \\
\pm 1.97\end{array}$ & $\begin{array}{r}5.7 \\
\pm 0.6\end{array}$ & $\begin{array}{r}4.0 \\
\pm 0.5\end{array}$ & $\begin{array}{r}5 \\
\pm 13\end{array}$ & $\begin{array}{r}860 \\
\pm 337\end{array}$ & $\begin{array}{r}0.94 \\
\pm 1.85\end{array}$ \\
\hline $\begin{array}{l}\text { TVC dogs } \\
\qquad(\mathrm{n}=10)\end{array}$ & $\begin{array}{r}66 \\
\pm 21\end{array}$ & $\begin{array}{r}82 \\
\pm 22\end{array}$ & $\begin{array}{r}170 \\
\pm 49\end{array}$ & $\begin{array}{r}212 \\
\pm 101\end{array}$ & $\begin{array}{r}4 \\
\pm 2\end{array}$ & $\begin{array}{r}52 \\
\pm 43\end{array}$ & $\begin{array}{r}9.26 \\
\pm 3.13\end{array}$ & $\begin{array}{r}11.7 \\
\pm 3.2\end{array}$ & $\begin{array}{r}5.5 \\
\pm 0.4\end{array}$ & $\begin{array}{r}3.5 \\
\pm 0.3\end{array}$ & $\begin{array}{r}16 \\
\pm 11\end{array}$ & $\begin{array}{r}48 \\
\pm 42\end{array}$ & $\begin{array}{r}2.44 \\
\pm 2.52\end{array}$ \\
\hline $\begin{array}{l}\text { AVC dogs } \\
\quad(n=10)\end{array}$ & $\begin{array}{r}62 \\
\pm 16\end{array}$ & $\begin{array}{r}62 \\
\pm 22\end{array}$ & $\begin{array}{r}160 \\
\pm 28\end{array}$ & $\begin{array}{r}157 \\
\pm 41\end{array}$ & $\begin{array}{r}20 \\
\pm 26\end{array}$ & $\begin{array}{r}363 \\
\pm 283\end{array}$ & $\begin{array}{r}8.75 \\
\pm 2.17\end{array}$ & $\begin{array}{r}8.92 \\
\pm 2.99\end{array}$ & $\begin{array}{r}5.8 \\
\pm 0.6\end{array}$ & $\begin{array}{r}3.7 \\
\pm 0.2\end{array}$ & $\begin{array}{r}0 \\
\pm 14\end{array}$ & $\begin{array}{r}343 \\
\pm 267\end{array}$ & $\begin{array}{r}0.17 \\
\pm 1.88\end{array}$ \\
\hline $\begin{array}{l}\text { p values } \\
\text { TVC rs. control } \\
\text { AVC vs. control } \\
\text { TVC vs. AVC }\end{array}$ & & & & & & & & & & & $\begin{array}{l}<0.05 \\
>0.05 \\
<0.02\end{array}$ & $\begin{array}{l}<0.01 \\
<0.01 \\
<0.01\end{array}$ & $\begin{array}{l}<0.05 \\
>0.05 \\
<0.02\end{array}$ \\
\hline
\end{tabular}

* See Tables I and II for abbreviations.

† Data from 13 control dogs, six TVC dogs, and six AVC dogs.

$\ddagger$ Pre and post indicate values before and after infusion of saline.

be due, in part at least, to the corresponding reduction of $1,000 \mu \mathrm{Eq}$ per minute in filtered sodium after saline infusion.

Data from paired experiments in seven dogs are illustrated in Figure 2. In each study, the increase in sodium excretion in response to saline loading was less after AVC constriction. In dogs 1 and 2, filtered sodium was higher during AVC constriction than in the control state. In $\operatorname{dog} 3$, filtered sodium was in the same range in both experiments, but postsaline filtered sodium was not so high after AVC constriction as in the control study. In dogs 4 through 7, filtered sodium was definitely lower after AVC constriction. Thus, in five of seven paired studies, decreased sodium excretion in the AVC dogs may be related to lower filtered sodium after saline infusion. Data from these seven experiments and from three additional studies in which paired control experiments were not done are summarized in Table III. Changes in sodium excretion, GFR, and filtered sodium in these experiments were quite variable. Mean sodium excretion increased $343 \mu \mathrm{Eq}$ per minute after saline loading in the AVC dogs, significantly less than the increase of $860 \mu \mathrm{Eq}$ per minute in the controls, but significantly more than the increase of only $48 \mu \mathrm{Eq}$ per minute in the TVC dogs. Mean GFR was not changed after saline infusion; filtered sodium increased slightly. The decrease in plasma protein concentration after saline infusion in the AVC dogs was comparable to that in the other two groups, suggesting that a similar proportion of the saline remained in the plasma compartment.

Acute TVC dogs. Five dogs were infused stepwise with $4 \mathrm{~L}$ of saline $1 \frac{1}{2}$ hours after con-

TABLE IV

Sodium excretion and glomerular filtration rate (GFR) in acute and chronic $T V C$ dogs during increasing saline infusions

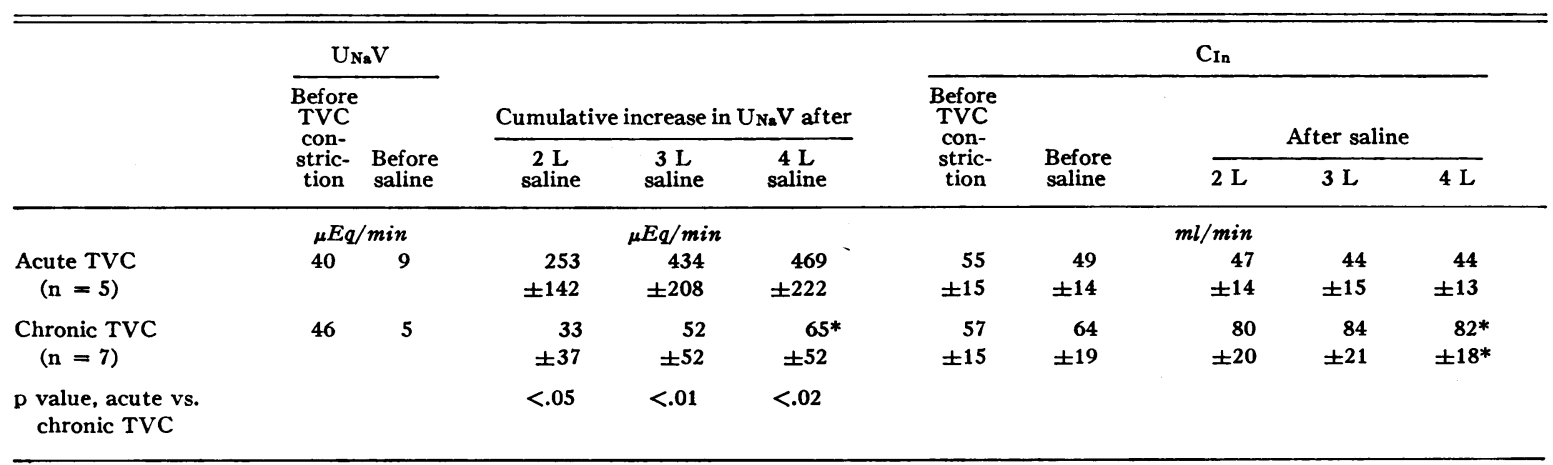

* Data from five dogs. 
striction of the TVC. Seven chronic TVC dogs were similarly challenged. The effect of progressive infusion of large volumes of saline on sodium excretion and GFR is summarized in Table IV. The sodium excretory response of the acute TVC dogs to $2 \mathrm{~L}$ of saline was much reduced as compared to control dogs (Table III), but definitely greater than that of the chronic TVC dogs. After infusion of 3 and $4 \mathrm{~L}$, sodium excretion rose to over $400 \mu \mathrm{Eq}$ per minute in the acute TVC dogs, but showed little change in the chronic dogs. The difference in sodium excretion at each level of infusion was statistically significant. GFR fell moderately after acute TVC constriction and showed a tendency to decrease further subsequently during saline infusion. The fall in GFR may account in part for the diminished sodium excretory response of the acute TVC as compared to the control dogs, in which GFR rose after saline (Table III). GFR after chronic TVC constriction was higher than in control studies on the same dogs. GFR rose markedly during infusion of the first $2 \mathrm{~L}$ of saline and was approximately stable thereafter.

\section{Discussion}

The normal dog responds to saline infusion with prompt sodium diuresis, a response that is almost completely eliminated in TVC dogs. The infusion of more than $2 \mathrm{~L}$ of saline within a 2 -hour period increased sodium excretion only $48 \mu \mathrm{Eq}$ per minute in TVC dogs. This is to be contrasted with the increase of $860 \mu \mathrm{Eq}$ per minute in normal dogs. These data from acute loading studies confirm and extend previous observations of almost complete chronic renal retention of smaller amounts of dietary salt $(1,2,7)$. It is generally assumed that the prompt increase in GFR that follows saline infusion is one factor in the ability of the normal dog to eliminate sodium rapidly. The complete sodium retention of TVC dogs cannot be due to inadequate renal hemodynamic response to saline infusion. In fact, the increase in GFR and filtered sodium in these dogs was three times as great as in the controls. Furthermore, TVC constriction does not cause chronic depression of the basal, presaline GFR. Mean GFR before saline loading was higher in the TVC dogs than in the controls (Table III). In five of seven paired studies (Figure 1), filtered sodium after saline loading in the TVC dogs was equal to or greater than filtered sodium in the controls. These data eliminate both chronic depression of basal GFR and decreased acute response of GFR to saline loading as causes of the renal sodium retention. All dogs received large doses of potent mineralocorticoids both before and during all saline infusion experiments. Hence, the increase in endogenous secretion (4) and decrease in hepatic degradation (6) of aldosterone known to occur in TVC dogs cannot account for the difference in sodium excretion. As already noted, studies by Davis and associates (5) in which the kidney of a uninephrectomized TVC dog, transplanted to the neck, continued to retain sodium have demonstrated that intact renal nerves and increased renal venous pressure are not necessary for sodium retention in TVC dogs. The latter point is also confirmed by the observation that renal sodium retention was not complete in the AVC dogs, although renal venous pressure in this group was the same as in the TVC dogs. Thus none of the factors usually invoked to explain sodium retention account for the observations in the TVC dogs.

Recently, the renal response to saline infusion in normal dogs has been restudied in several laboratories $(9,11,12)$. It has been found that at least part of the increase in sodium excretion after saline loading is not caused by the associated increase in filtered sodium, nor by a change in aldosterone activity. The data do not permit exact quantitative separation of postsaline sodium diuresis into that fraction due to increased filtered sodium and that due to decreased tubular reabsorption, but the latter seems to account at least for several hundred microequivalents per minute $(9,11,12)$. The existence of the new factor(s) that inhibits sodium reabsorption was demonstrated by experiments in which sodium excretion increased after saline loading, even if filtered sodium was reduced below control levels. In the report from our laboratory (9), when sodium excretion after saline infusion was set $97 \mu \mathrm{Eq}$ per minute above control by aortic clamping, filtered sodium was $1.23 \mathrm{mEq}$ per minute below control. In the TVC dogs, sodium excretion was $48 \mu \mathrm{Eq}$ per minute above control after saline loading. At this time, filtered sodium was 0.94 $\mathrm{mEq}$ per minute above control. Thus, with 
equivalent slight increases in sodium excretion during saline loading, tubular reabsorption appears to be increased in TVC dogs and decreased in normal dogs. Absence or inhibition in TVC dogs of the new factor that inhibits tubular reabsorption can also be inferred from other observations. In six of the 14 control dogs (Figure 1, dogs 3, 4, 6, and 7; Figure 2, dogs 1 and 7) sodium excretion increased after saline infusion in spite of spontaneous decreases in filtered sodium. A similar response occurred in six of ten AVC dogs (Figure 2, dogs, 4, 5, and 7 ; three dogs included in Table III, but not shown in Figure 2). These experiments represent spontaneous demonstrations of the operation of the new factor that decreases tubular reabsorption of sodium. A similar demonstration can be seen in the data from acute TVC dogs in Table IV. When the TVC was constricted acutely, GFR fell from 55 to 49 $\mathrm{ml}$ per minute, and sodium excretion fell from 40 to $9 \mu \mathrm{Eq}$ per minute. Thereafter, saline was infused, and in spite of a tendency for GFR to decrease further (49 to $44 \mathrm{ml}$ per minute), sodium excretion rose progressively to $478 \mu \mathrm{Eq}$ per minute. In none of the ten chronic TVC dogs did the phenomenon of increased sodium excretion with decreased filtered sodium occur, even when as much as $4 \mathrm{~L}$ of saline was infused (Figure 1, Table IV). Thus, there is no evidence that tubular reabsorption is depressed by saline loading in TVC dogs. We cannot determine from the present data whether the factor that decreases reabsorption does not become operative in TVC dogs or whether its operation is masked by a potent opposing mechanism that increases tubular sodium reabsorption. Definition of the exact role of this new factor in sodium retention obviously must await more complete description of the nature of the factor itself.

The TVC dogs demonstrated profound sodium retention. The AVC dogs had a variable sodium excretory response statistically less than the control response but more than the natriuresis in TVC dogs. Sodium excretion was greater in AVC than in TVC dogs in spite of the fact that GFR increased much more after saline in the TVC dogs. The decreased sodium diuresis in the AVC dogs as compared to the controls may, in part at least, be due to the failure of GFR to increase in the AVC dogs. These differences in sodium excretion in acute studies fit well with the observations that TVC, but not AVC, dogs retain sodium chronically $(1,13)$.

Only the hepatic veins enter the vena cava between the point at which the vena cava was tied in the AVC dogs and the point of constriction in the TVC dogs. The difference in the response to saline loading between the TVC and AVC dogs suggests the possibility that the liver or some other organ in the portal circulation is involved in the regulation of tubular sodium reabsorption. The difference in sodium excretion cannot be due to differences in renal venous pressure. Mean pressure in the vena cava at the point of entrance of the renal veins before saline infusion was $21 \mathrm{~cm}$ of saline in the TVC, 20 in the AVC dogs; after infusion, 32 in the TVC, 33 in the AVC dogs. The equivalent dilution of plasma proteins in both groups suggests that the infused saline remained in the vascular compartment to a similar extent. Thus, differences in filtered sodium, renal venous pressure, and expansion of the blood volume do not account for the difference in sodium excretion. It is possible that the infused saline is trapped in the liver or portal circulation in the TVC dogs, thereby removing it from the "effective" blood volume. However, the infusion of $4 \mathrm{~L}$ of saline into TVC dogs (Table IV) increased sodium excretion less $(p<0.05)$ than the infusion of $2 \mathrm{~L}$ into AVC dogs (Table III). It seems unlikely that the infusion of 2 additional $\mathrm{L}$ of saline would not increase sodium excretion in TVC dogs to the levels in AVC dogs, if the only difference were trapping of the saline in the hepatic or portal circulation. The observation that sodium retention is less complete in acute than in chronic TVC dogs, especially after large saline loads (Table IV), also suggests that trapping of saline within the hepatic and portal circulations is not alone sufficient to account for the virtually complete sodium retention in chronic TVC dogs. It is possible that the congested circulation has an increased capacity to sequester saline after chronic as compared to acute TVC constriction. However, the greater sodium excretion after $2 \mathrm{~L}$ of saline in the acute TVC dogs than after $4 \mathrm{~L}$ in the chronic TVC dogs $(\mathrm{p}<0.05)$ is against this explanation for the difference in excretion between acute and chronic TVC dogs. 
As already noted, tubular sodium reabsorption does not decrease during saline infusion in chronic TVC dogs. On the contrary, tubular reabsorption in acute TVC dogs decreases as much as in controls during saline loading. ${ }^{2}$ Acute TVC studies were completed within 7 hours of TVC constriction, and chronic TVC experiments were not begun until at least 48 hours after constriction. Hence, tubular sodium-retaining mechanisms apparently first become operative in the interval between 7 and 48 hours after constriction.

Thus, chronic TVC constriction results in uniform, profound renal sodium retention, which is virtually complete even after large saline infusions. AVC or acute TVC constriction also frequently causes marked renal sodium retention after moderate saline loads, but this is less uniform, less complete, partly reversible by larger infusions, and probably partly related to decreased GFR. One reasonable interpretation of these data is that they reflect differences in trapping of infused saline in a congested venous circulation outside the "effective" circulating blood volume. However, the various indirect arguments presented above suggest the possibility that there is a qualitative difference between chronic TVC constriction and the other states of venous constriction studied. Chronic congestion of the liver (or some other organ in the portal circulation) may result in the formation of a humoral factor other than aldosterone that directly enhances renal tubular sodium reabsorption, or it may prevent the release of a humoral factor that normally decreases tubular sodium reabsorption after saline. Alternatively, some subtle alteration in renal hemodynamics may occur, mediated either by a hormone or by volume or pressure changes in the arterial circulation.

\section{Summary}

1. The response to acute saline infusions was studied in four groups of dogs, all treated with large doses of mineralocorticoids: $a$ ) controls; b) TVC dogs, in which the inferior vena cava had been constricted in the thorax 2 to 8 days

\footnotetext{
2 In acute TVC dogs, sodium excretion increased 253 $\mu \mathrm{Eq}$ per minute after $2 \mathrm{~L}$ of saline, despite a spontaneous decrease in GFR. This is quite similar to the increase in excretion in control dogs in which GFR was comparably reduced by aortic clamping (9).
}

before study; c) AVC dogs, in which the vena cava had been constricted just above the renal veins 2 to 8 days before study; $d$ ) acute TVC dogs, in which the inferior vena cava had been constricted in the thorax $1 \frac{1}{2}$ hours before study.

2. In control dogs sodium excretion increased $860 \mu \mathrm{Eq}$ per minute, and glomerular filtration rate (GFR) increased $5 \mathrm{ml}$ per minute after $2 \mathrm{~L}$ of saline. In TVC dogs, sodium excretion increased only $48 \mu \mathrm{Eq}$ per minute, in spite of an increase of $16 \mathrm{ml}$ per minute in GFR. In AVC dogs, sodium excretion increased $343 \mu \mathrm{Eq}$ per minute; GFR was variable, but, on the average, unchanged.

3. In seven paired experiments, the same dog was studied as a control and as a TVC dog. In five dogs, GFR both before and after saline loading as a TVC dog was higher than in the control study, yet sodium excretion in the TVC studies was markedly reduced.

4. There was little or no tendency for sodium excretion to increase in spite of increased GFR, even after progressive infusion of up to $4 \mathrm{~L}$ of saline in chronic TVC dogs. In acute TVC dogs, sodium excretion was $253 \mu \mathrm{Eq}$ per minute above presaline values after $2 \mathrm{~L}$ of saline and increased progressively to $469 \mu \mathrm{Eq}$ per minute above presaline levels after $4 \mathrm{~L}$, in spite of decreased GFR.

5. It is concluded that the striking sodium retention in chronic TVC dogs is not due to decreased basal or postsaline GFR. The decrease in tubular reabsorption of sodium that occurs in normal dogs after saline loading is not manifested in TVC dogs, either because it does not become operative or because it is masked by a potent opposing mechanism. The difference in response of the TVC and AVC dogs suggests that the liver, or some other organ in the portal circulation, may be involved in the regulation of sodium excretion.

\section{References}

1. Davis, J. O., and D. S. Howell. Mechanisms of fluid and electrolyte retention in experimental preparations in dogs. II. With thoracic inferior vena cava constriction. Circulat. Res. 1953, 1, 171.

2. Davis, J. O., D. S. Howell, and J. L. Southworth. Mechanisms of fluid and electrolyte retention in experimental preparations in dogs. III. Effect of 
adrenalectomy and subsequent desoxycorticosterone acetate administration on ascites formation. Circulat. Res. 1953, 1, 260.

3. Davis, J. O., D. S. Howell, M. J. Goodkind, and R. E. Hyatt. Accumulation of ascites during maintenance of adrenalectomized dogs with thoracic inferior vena cava constriction on a high sodium diet without hormone therapy. Amer. J. Physiol. 1956, 185, 230.

4. Davis, J. O., M. M. Pechet, W. C. Ball, Jr., and M. J. Goodkind. Increased aldosterone secretion in dogs with right-sided congestive heart failure and in dogs with thoracic inferior vena cava constriction. J. clin. Invest. 1957, 36, 689.

5. Carpenter, C. C. J., J. O. Davis, J. E. Holman, C. R. Ayers, and R. C. Bahn. Studies on the response of the transplanted kidney and the transplanted adrenal gland to thoracic inferior vena caval constriction. J. clin. Invest. 1961, 40, 196.

6. Ayers, C. R., J. O. Davis, F. Lieberman, C. C. J. Carpenter, and $M$. Berman. The effects of chronic hepatic venous congestion on the metabolism of $d, l$-aldosterone and $d$-aldosterone. J. clin. Invest. 1962, 41, 884.

7. Davis, J. O., J. E. Holman, C. C. J. Carpenter, J. Urquhart, and J. T. Higgins, Jr. An extraadrenal factor essential for chronic renal sodium retention in presence of increased sodium-retaining hormone. Circulat. Res. 1964, 14, 17.

8. Stamler, J., H. Goldberg, A. Gordon, M. Weinshel, and L. N. Katz. Relationship of elevated renal venous pressure to sodium clearances and edema formation in unanesthetized dogs. Amer. J. Physiol. 1951, 166, 400.

9. Levinsky, N. G., and R. C. Lalone. The mechanism of sodium diuresis after saline infusion in the dog. J. clin. Invest. 1963, 42, 1261.

10. Snedecor, G. W. Statistical Methods, 4th ed. Ames, Iowa State College Press, 1946, p. 83.

11. Rector, F. C., Jr., G. Van Giesen, F. Kiil, and D. W. Seldin. Influence of expansion of extracellular volume on tubular reabsorption of sodium independent of changes in glomerular filtration rate and aldosterone activity. J. clin. Invest. 1964, 43, 341.

12. DeWardener, H. E., I. H. Mills, W. F. Clapham, and C. J. Hayter. Studies on the efferent mechanism of the sodium diuresis which follows the administration of intravenous saline in the dog. Clin. Sci. 1961, 21, 249.

13. Hwang, W., L. C. Akman, A. J. Miller, E. N. Silber, J. Stamler, and L. N. Katz. Effects of sustained elevation of renal venous pressure on sodium excretion in unanesthetized dog. Amer. J. Physiol. 1950, 162, 649. 